\title{
Culture and Mentality in East-Nordic Courts
}

\author{
Laura Ervo
}

\begin{abstract}
In this chapter, the East-Nordic, that is Finnish and Swedish, court culture and mentality and its historical, cultural and societal roots are explored. The objective of the chapter is to uncover the mechanisms underlying the East-Nordic court mentality and the hallmarks of Swedish and Finnish court culture, as well as to identify how these processes influence adjudication. Emphasis is put on the historical development of these countries, since Finland was part of Sweden until 1809. After Finland became an autonomous Grand Dutchy of the Russian Empire, it suffered under Russification, whereas Sweden was still part of the western sphere. Even after Finland gained independence in 1917, the history of the two countries has differed to some extent. Therefore, it is interesting to explore the manner in which the differences in history are manifested in contemporary court proceedings. This study is based mainly on comparative and historical resources.
\end{abstract}

\section{Starting Points}

The term legal culture often refers to a particular legal tradition, a set of legal institutions that has evolved with historical development, and the way in which justice is practiced. Legal culture has been examined, for example, in terms of the number of trials, attitudes towards legal institutions, legal rhetoric and legal ideology. Expressions such as European legal culture, Nordic legal culture and national legal culture are also often used. ${ }^{1}$

Legal culture can be further divided into two sub-areas. Namely, it is possible to refer in a more elitist way to the legal profession and their activities or in a more popular way to the people's perceptions of the justice, courts and law. Therefore, legal culture can mean the way in which law is practiced or how people react to it. Legal culture can also include legal practitioners, like judges, prosecutors, attorneys

${ }^{1}$ Ervasti (2005), p. 352.

L. Ervo $(\bowtie)$

School of Law, Psychology and Social Work, Örebro University, 70182 Örebro, Sweden e-mail: Laura.ervo@oru.se 
and so on, as well as their practices. Also, the specific language constituting legal concepts and terms and legal procedures at the courts are included into the legal culture. As part of a legal culture, there is often talk of a court culture. In the broadest sense, legal culture refers to the whole legislation, judiciary and legal conditions of a state or group of states. If understood in this way, legal culture is one part in the concept of culture as a whole. ${ }^{2}$

As mentioned above, court culture is a part of legal culture. It refers to the culture of courts, including procedures and professions. In turn, court mentality is a part of court culture. It consists of a judge's mental set of tools, those psychological instruments and habits with which he or she fulfils his or her professional duties and acts as a citizen in society. The judge's characteristics, education, environment and worldview are included in this set as well. ${ }^{3}$ The court mentality can therefore be summarised as a judge's psychological toolbox.

Whenever legal decisions are made, decision makers' personal ways of thinking as well as their ideology are in play. It must be admitted that adjudication is not an exact science or a strictly technical subject. Courts' objectivity and judges' impartiality are, of course, very fundamental legal principles and the starting point of the whole adjudication as such. Still, the mentality including, for instance, judges' ideology cannot be totally avoided. The significance of these types of factors in the decision making should be taken seriously. ${ }^{4}$ They cannot be totally avoided even if a judge is well educated and working in a very professional way. This is why it is important to research the court culture including court mentality and how it affects decision making.

In this article, the East-Nordic court culture and mentality as well as reasons for them are researched and compared with each other. The reasons are sought mainly in the history. The objective of the chapter is to find out how the East-Nordic court mentality works and what kinds of ingredients are included in the Swedish and Finnish court culture. Subsequently, the findings should help to illustrate how everything described above all this affects the adjudication. However, it has not been the aim to research how court culture or judges' mentalities affect decision making in single cases but rather research the phenomenon as such and in general. Therefore, no empirical studies are conducted, and the traditional legal method is used. What the behaviour and mentality are concerned, also the auto ethnography is used. ${ }^{5}$ The references consist mainly of resources of comparative law and legal history.

As a starting point, the investigation uses the concept of Nordic law, which forms a legal family despite civil law and common law distinctions. According to Husa, the most relevant similarities do not concern formal legal rules but rather the legal mentality in the Nordic countries. ${ }^{6}$ Also Letto-Vanamo and Tamm talk about the

\footnotetext{
${ }^{2}$ Ervasti (2005), p. 352.

${ }^{3}$ Kemppinen (1992) and Yrttiaho (2000), p. 292.

${ }^{4}$ Hautamäki (2004), pp. 133.

${ }^{5}$ The author has quite a long working experience in both countries in question.

${ }^{6}$ Husa (2010), p. 6.
} 
Nordic mind or 'Nordic-ness' instead of the Nordic law. ${ }^{7}$ This is because certain basic values concerning social justice, social ethics and law in general are similar in the region. Because of the close relationship of Nordic jurisdictions and their common stylistic hallmarks, they form a special legal family. ${ }^{8}$

\section{Reasons in History}

\subsection{Swedish Origins}

The earliest substantial Swedish law texts are the provincial laws, which were the means of law-holding in Sweden during the Middle Ages. Around 1200, the laws began to be transferred to written form. This was probably due to clerical influences. The oldest of the Swedish provincial laws is the Västgötalagen, which was used in the west part of Sweden. Around 1350, the Swedish provincial laws were replaced by the Magnus Eriksson country law. ${ }^{9}$

Mostly three factors, namely societal development, Christianity and the reception of the foreign law have affected the development of the Swedish legal culture. ${ }^{10}$ Also, the German-Roman tradition had an important influence on the Swedish legal system. A comprehensive Swedish code was enacted in 1734. This code, known as The Code of 1734, was divided into the following sections: The Books on Marriage, Inheritance, Land, Building, Commerce, Crimes, Judicial Procedure and the Book on Execution of Judgements. This structure can still be found in the Swedish law book. In addition, there are some later codes, namely, the Parental Code (1949), the Environmental Code (1998) and the Social Insurance Code (2010). ${ }^{11}$

During the seventeenth century, Sweden emerged as a great power by taking direct control of the Baltic region. Sweden's role in the Thirty Years' War determined the political and religious balance of power in Europe. In 1721, Russia and its allies won the war against Sweden, marking an end to the Swedish superpower in Europe. Sweden joined in the Enlightenment and, between 1570 and 1800, experienced two periods of urban expansion. ${ }^{12}$

Sweden's last war was the Swedish-Norwegian War in 1814. Sweden won the war, and, as a result, Norway formed a union with Sweden that lasted until 1905. Since 1814 , Sweden has been at peace, adopting a non-allied foreign policy in peacetime and neutrality in wartime. During World Wars I and II, Sweden remained neutral. Additionally, Sweden attempted to stay out of alliances and remain officially neutral

\footnotetext{
${ }^{7}$ Letto-Vanamo and Tamm (2019), pp. 1 and 9.

${ }^{8}$ Husa (2010), p. 6.

${ }^{9}$ Inger (2011), p. 13-17.

${ }^{10}$ Inger (2011), p. 9.

${ }^{11}$ Ortwein (2003), p. 411.

${ }^{12}$ Inger (2011), p. 75 and 78.
} 
during the entirety of the Cold War. The social democratic party held the government for 44 years (1932-1976). ${ }^{13}$

\subsection{Sweden-Finland and Its Effects}

As explained above, the East-Scandinavian countries, namely Sweden and Finland, have a common history. From the 1200s onwards, Finland constituted the eastern part of Sweden, a status that continued until 1809. Before the Swedish period, there was no state or central power in Finland. Centralised power and nationwide legislation started to develop simultaneously during the Swedish period. ${ }^{14}$ Therefore, both countries share the same origins in terms of the legal system and principles.

Due to this common history, and especially the common legislative tradition which survived in modern-day Finland for quite a long time, the prerequisites for common court culture are quite unique. The fact that legal systems, with their main principles, are still rooted in the same formal basis provides a guarantee that key legal concepts and principles are in fact understood in a similar way in both countries. Thanks to the shared religion, the value base is shared as well. This common morality affects the legal interpretations despite the fact that both countries are rather secularised. ${ }^{15}$ Values of honesty and a strong work ethic are among the fruits of that Lutheran morality. ${ }^{16}$

\subsection{Finland as Autonomous Grand Duchy of the Russian Empire and Russification}

In 1809, Finland became an autonomous part of Russia; even then, however, Swedish laws remained in force and continued to be valid throughout the whole Russian period. Indeed, the Russian legal system did not have much of an effect in Finland, where the Swedish model remained prevalent up to and including the establishment of Finland as an independent country in $1917 .^{17}$

More generally speaking, Finland is said to be the border between the West and East due to the fact that, both geographically and historically, Finland is located between Sweden and Russia. The religions of the regions differ (Orthodox in Russia and Lutheran in Sweden and Finland), and thus the values and ways of thinking differ as well. These differences can be seen in the local culture, which varies between the western and eastern parts of Finland. Eastern Finland, which is closer to the Russian

\footnotetext{
${ }^{13}$ Inger (2011), p. 307.

${ }^{14}$ Ervo (2014b), pp. 386-390.

${ }^{15}$ Ervo (2014a).

${ }^{16}$ More about this see Husa et al. (2007), pp. 23-24.

${ }^{17}$ Ervo (2014b), p. 250.
} 
border, shows more similarities with the Russian lifestyle. For instance, there is an Orthodox religious minority in the eastern part of Finland.

It is difficult to ascertain without comprehensive empirical studies whether this border situation affects the court culture. Therefore, it is also impossible to say whether and how these cultural differences between the eastern and western parts of Finland as such could affect the court culture, which is legally bound and based on common statutes. At first glance, such differences might be assumed to be very small, due to the fact that court culture is a professional culture and therefore it is consisting partly of legally bound parts-in the other words, it is not only about culture but also about professional duties My experience-after working quite a long time in both named countries - and answer is that the Finnish court culture is very western due to the Swedish origins and the country's current situation as one of the Nordic countries. It can also be said that there are no great difference in the court culture between the western and eastern part of Finland, because the question relates to a professional and legally bound culture at courts. Still, the Finland's position as a borderline and its potential effects on the court culture is interesting and should be researched further. ${ }^{18}$ However, let's return to the historical development again.

From 1890 onward, a policy of 'Russification' was introduced, and this era is therefore sometimes called the period of oppression. The policy's aim was arguably to make Finland more Russian. However, whenever certain Russian exceptions were made in the field of legislation, the Finnish legal services protested widely, and the new system was never fully followed. Notably, these exceptions made in the field of legislation still only covered some aspects of the legal system, while other aspects were still officially and formally legislated by the Finnish (formerly Swedish) laws only. $^{19}$

The Code for Juridical Procedure, for instance, has been valid without any breaks from 1734 until today, ${ }^{20}$ despite the historical vicissitudes wherein Finland was a part of Sweden, an autonomous part of Russia and an independent state, respectively. ${ }^{21}$ Seldom is one code so sustainable that it stays valid through three different empires. Despite of the reforms in contents, the same structure is mainly followed even today. The reason for this must be in the deep correspondence of the code's contents with

\footnotetext{
${ }^{18}$ Still, there are many comparative studies between Finland and Sweden. For instance, in Karonen and Östberg (2018) Finland and Sweden have been compared with each other from historical and political perspectives. There are also some comparisons based on geography or geopolitics. Karonen and Östberg (2018), pp. 433-434. However, the pure cultural aspects do not play a big role in this research. Also, for instance Niemi and Kiesiläinen (2007) and Niemi (2018) has compared Sweden and Finland from the legal perspective. She pays attention especially in the legal theory point of view. Niemi and Kiesiläinen (2007), pp. 89-108 and Niemi (2018), pp. 230-244. Closest with the similar perspective comes Husa et al. (2007), pp. 1-36. Also there the legal situations in Finland and Sweden are compared with the historical and cultural points of view.

${ }^{19}$ Ervo (2014b), p. 250.

${ }^{20}$ This does not mean that the contents were not reformed and updated. However, the code as such has never been abolished but the reforms have always updated the contents bit by bit. Therefore, for instance, the structure is still mainly the same.

${ }^{21}$ Ervo (2014b), p. 250.
} 
the local values (i.e., morality) and the way of thinking (i.e., mentality) and therefore culture (i.e., the context of morality and mentality together).

During the autonomous period, legislative reforms were not easy to realise in Finland. Therefore, the Finnish legislation was for some time static and not subject to development. The Russian period and its challenges led to rapid developments in independent Finland and to some flexibility in applying and interpreting laws to correspond with the demands in the current society. It is said that since then, legal reforms have usually been realised quickly without wide societal discussion. One of the main goals has been effectiveness. ${ }^{22}$ The other effect from the Russian period is that of easily adopted new interpretations in the case law whenever needed, if the legislator has not reacted to current needs in the society. This makes flexibility, creative solutions and common-sense trademarks of the Finnish legal culture, which from the more careful Swedish perspective could even be described imaginative. ${ }^{23}$

Especially in Finland, legal problems which are not covered by a specific statutory provision are often solved by applying analogical principles expressed in the other statutes or by supplementing case law. Additionally, in the uncodified or only insufficiently codified areas, legal doctrine plays an important role. ${ }^{24}$ This is especially true in Finland.

It has been argued that especially this part of the Finnish history-the period of autonomy and ensuing legislative challenges-have marked Finnish legal culture and made it what it is today. Moreover, Russification caused an emphasis on legality ${ }^{25}$ to take root among civil servants, and this culture of legality still affects the current system. ${ }^{26}$ However, not all scholars share this explanation. Björne, for example, is of the opinion that the passive resistance of the Finnish civil servants and the countermeasures made against the nationwide (Russian) legislation did not have much to do with the legalism as such but were more based on the will to interpret laws as the interpreter desired. Björne also discusses the Finnish legalism further and illustrates his opinion that the legalism is just a myth with a number of sad historical examples, like trials after the civil war. ${ }^{27}$

\footnotetext{
${ }^{22}$ Kekkonen (1998a), p. 936 and Saarnilehto (2003), p. 74. In the latter source it is said that those problems were solved between 1917 and 1995.

${ }^{23}$ Sallila (2011), p. 466. Nylund and Sunde have described the Nordic court culture in general as pragmatic and creative. Nylund and Øyrehagen Sunde (2019) p. 201. It is for sure true. It is up to which one is comparing. At large and compared with other countries, the Nordic culture as such is creative and pragmatic. However, when compared single Nordic countries with each other, some differences at this inside level can be found. Also, in Letto-Vanamo and Tamm (2019) the Nordic legal culture as such is described as pragmatic and uncomplicated. Letto-Vanamo and Tamm (2019), p. 9 .

${ }^{24}$ Bernitz (2007), p. 20.

${ }^{25}$ According to the Oxford English Dictionary, legality refers to the quality or state of being in accordance with the law.

${ }^{26}$ Aalto (1976), pp. 40-42, Jussila (2004), p. 254, Kekkonen (1998b), pp.162-163 and Kemppinen (1999) and Virtanen (1974), pp. 11-410.

${ }^{27}$ Björne (2012), pp. 149-152. Compare for instance with Letto-Vanamo and Tamm (20f19), pp. 7-8 where Finland is named as a more legalistic country than the other Nordic countries.
} 
However, these types of tragedies linked with wars and other exceptional circumstances, like trials after the civil war or the war-responsibility trials in Finland after the Second World War, cannot be used as daily-life examples. They are of a political nature, and therefore neither the legalism nor the legal protection was fully (or even partially) realised. Of course, the depth of the legalism and the legal protection of the society will be tested under exceptional circumstances, and if the practice will stand even then, then legalism and the legal protection can be said to be fully in force. Usually, the legalism will work during good times, but whenever societal (political) problems arise, the violations unfortunately start to become more common.

The role of legality can also be challenged in Finland today. Of course, in both Sweden and Finland legality is highly appreciated as one of the most important principles in legal democracy and rule of law. Still, the notion that legality plays a bigger role in Finland compared with Sweden or other Nordic countries can be argued to be a myth. I would say that the myth is the role of the legality in Finland as such, not its background and reasons for it. I would also argue that there are not major differences in experiencing and realizing legality in the Nordic countries. It is a basic tenet in the Nordic law as a matter of fact. Perhaps the situation would have be different in Finland earlier, such as at the beginning of the country's independence, when the signs of Russian period still were in people's minds and had a greater effect than they do today.

Also, the judicial activism as well creative and instrumentally acting courts and judges in Finland are facts which tells us that in a very pedant way interpreted legality is probably not the most important aim. If the legality were taken in a very strict and formal way, there would not be much space for judicial activism or creative, practical solutions. However, these above-named effects; creative interpretations and respect of legality do not directly correspond with each other but in fact are quite opposite tools to handle difficult and undesirable political situations.

Reality and daily life at courts looks very different today than in the early 1920s. There are new challenges like multiculturalism and globalisation thanks to which clients at courts represent many different cultures and speak many different languages. At the end of 2019, there were about $19.56 \%$ foreign inhabitants (born abroad) in Sweden ${ }^{28}$ whereas the same figure for Finland in 2018 was $7 \% .{ }^{29}$ At the same time, cases are more international as well. Both criminality and business are no longer confined by state borders but have an international and cross-border character. Therefore, judges need to know how to tackle these types of cultural differences and language problems and how to decide cases which are not based only on the national law. In this modern context, the strict respect of legality or origins to that type of previous legal culture in Finland seem no longer to be current issues. The daily-life situations show that many other problems and values have become more current by time.

\footnotetext{
${ }^{28} \mathrm{https}: / /$ www.scb.se/hitta-statistik/statistik-efter-amne/befolkning/befolkningenssammansattn ing/befolkningsstatistik/. Accessed 14 June 2020.

${ }^{29} \mathrm{https}$ ://www.tilastokeskus.fi/tup/maahanmuutto/maahanmuuttajat-vaestossa/ulkomailla-syntyn eet.html. Accessed 14 June 2020.
} 


\subsection{The Main Cornerstones in Recent History Until Today}

When the Finnish Parliament adopted the Declaration of Independence of Finland on the 6th of December 1917, the new state thus already had a rich national culture and centuries of experience in managing its own affairs. As explained above, the makings of the independent nation stem partly from the times of Swedish rule (from the thirteenth century until 1809) and especially from the period when Finland was an autonomous Grand Duchy of the Russian Empire (1809-1917).

Extra flavour was added to this cultural soup by the Finnish civil war in 1918 and its consequences, as well as by the Second World War and the war-responsibility trials, which were of an accentuated political nature. The latter incidents may likely have resulted in increased demands on democracy, the rule of law and legal protection. ${ }^{30}$ In the 1970s, unemployment caused a deep crisis in Finland, as did the economic depression in the beginning of the 90s; such periods have cultural and mental effects, ${ }^{31}$ not only in general but also specifically in the court culture. With these two and other potential crises still in their minds, the general audience and professional groups like judges and legislators are more sensitive when faced with difficult situations and the associated risks. It is easy to remember what things were like during times of crisis, and it is not forgotten that new crisis are still possible in the future. There is no belief that happy days will last forever. ${ }^{32}$

In Sweden, there have been no wars and more need for workers than unemployment; even the economy has consistently been relatively buoyant, at least compared with many other countries. The current COVID-19-crisis is the biggest crisis in the last 200 years.

In Sweden, the ideology of folkhemmet ${ }^{33}$ well illustrates recent Swedish societal history. It still profoundly affects the self-image ${ }^{34}$ of Swedes today. Nothing similar has occurred in Finland, even though both countries are welfare states. The idea of folkhemmet strongly affects Swedish culture and the Swedish way of living, especially with regard to social connections like working environment and labour law. It highlights the importance of group participation in decision-making (e.g., in the

\footnotetext{
${ }^{30}$ Kekkonen (1998a), p. 936.

${ }^{31}$ According to Lehtinen et al. (1995), the economic depression increased metal problems in Finland, pp. 323-329, whereas according to Viinamäki et al. (1997) the correlation is unclear. Still, in the latter study economic factors also seem to correspond with mental problems, p. 1689.

${ }^{32}$ See, for instance, Kiander (2001), pp. 131, where the results of a research program on the "1990s economic depression" of the Finnish Academy is presented. Also, Kekkonen pays attention to how economic depressions and other crises affect legal culture. See Kekkonen (1999), pp. 51, 88 and 93. How societal changes affect courts has been discussed in Tuomioistuinlaitoksen kehittämiskomitean välimietintö (committee report) 2003, pp. 18.

${ }^{33}$ Folkhemmet is a political concept that played an important role in the history of the Swedish Social Democratic Party and the Swedish welfare state. The core of the folkhem vision is that the entire society ought to be like a small family where everybody contributes. See more about the concept in, e.g., Dahlqvist (2002), pp. 445-465.

${ }^{34}$ Bertilsson (2010), p. 28.
} 
workplace). This social way of thinking arising from the folkhemmet ideology is very widespread throughout Swedish society.

This mindset affects legal culture as well, including the ways in which legal tools are used and laws are interpreted. The differences in juridical law-making can be explained by these societal reasons, which have led to two different court mentalities in the East-Nordic countries.

The discussion on legality, described above, its origins and meaning in daily life and during the exceptional circumstances, is current also today. The legality is not working in the same way during the exceptional times than in the normal daily life. It has been evident, for example, during the current COVID-19 period, when the government in Finland has given false information on the valid restrictions, most likely to make people more compliant. It has not clearly informed on the difference between recommendations and obligations. Because the parliament and government decided to implement emergency legislation, this type of unclear information has been deeply misleading. Under normal conditions, people can more easily estimate what is and is not legal, but a general audience cannot know the contents and limits of emergency legislation. For instance, Finnish citizens were not told that they could still come and go over the border based on their fundamental rights despite the emergency legislation. ${ }^{35}$ Only since the legal scholars started to pay attention to this lack in information, the written instructions were changed and for instance, ministers started to stress this in an oral way too. Still, I argue that it is not entirely appropriate to use exceptional political trials as daily-life examples. How the law should be interpreted and applied in daily life in routine cases should be researched as well. The situation as a whole should then be compared with the research target, like legality. Only if the legality is interpreted and followed strictly both in the daily life as well as during the exceptional circumstances, it is possible to draw conclusions which describe the local attitudes in general. The cases with political value are usually exceptional, and sadly often tragic, examples. Therefore, I would like to sum up that what Russification affected into the Finnish legality is no longer very current. The value of legality has become lower. Additionally, it must be stressed that the above described traditional effects from the periods of Russification are in contrast. On the one hand, legality is underlined in this context. On the other hand, the rapid reforms and creative case-law as a solution are mentioned too.

\footnotetext{
${ }^{35}$ For instance, the official newssheets on the website of the Finnish border guard https://www. raja.fi were misleading during the early stage of the pandemic. After the media and some professors debated the issue, they were adjusted and now it clearly whether the instructions are merely recommendations, or whether they are enforceable rules, and whether the restrictions apply only to foreigners, or also to Finnish citizens.

See for instance, https://yle.fi/uutiset/3-11487500, https://www.uusisuomi.fi/uutiset/apulai sprofessori-loytaa-useita-ongelmia-suomen-koronatoimista-ratkaisujen-tekeminen-on-karannutosin-pois-eduskunnan-kasista/1a415363-b0e5-46c0-8629-e0b1fd30a5de, https://svenska.yle.fi/ artikel/2020/05/07/manniskorattsprofessor-martin-scheinin-man-har-ansett-att-det-bara-ar-diktat urer, https://perustuslakiblogi.wordpress.com/2020/03/ and https://sverigesradio.se/artikel/746 8102. Accessed 11 Feb 2021.
} 


\section{Sweden as a Role Model}

The attitude towards the Swedish legal system has been extremely positive in Finland. Especially in the legislative culture, Sweden is usually seen as a good model which can safely be followed. Still, the Swedish model is not directly copied; instead, the Finnish legislator often is careful and waits for more thorough evaluation based on the Swedish experience before the Swedish model is followed in legislative reforms. By doing so, the Finnish legislator often uses Sweden as a test lab. This method is easy due to the common background and similarities in jurisdiction. Both EastNordic countries belong to the same Scandinavian legal family and additionally have a common history. This means that the legal system, legal principles and the court system are, if not identical, very similar to each other. Additionally, the surrounding society and the mentality of people is - at least at the macro level-very similar. This facilitates legal transplants. Actually, Swedish models or experiences are not even perceived as legal transplants in Finland but rather are seen more as a 'domestic product'. ${ }^{36}$ Based on the common history of Sweden and Finland, this is understandable. Still, much has happened in Finland since the Swedish period. Therefore, the common history cannot explain everything, but the main reasons for having Sweden as a role model, must be in the common culture, which still has effects due to geographical and mental similarities. This is why the Swedish transplants feel home-made.

Another reason for easily adopting Swedish reforms and learning from the Swedish experience, is the strong common East-Scandinavian jurist identity, which is built mostly by regular Nordic contacts and co-operation in practice. ${ }^{37}$ In daily life, Nordic lawyers and researchers frequently keep in touch, especially with their Swedish colleagues. Especially in Finland, the Swedish case law and scientific literature are carefully followed, referenced and used in the Finnish research but also, for instance, at courts by judges and attorneys. In Sweden, this tradition is less common due to the language barrier. All Finns can understand Swedish, but most Swedes cannot understand Finnish. The Finnish scientific literature written in Swedish language and court cases in Swedish are the clear minority even though Finland has two national languages, Finnish and Swedish. Therefore, the Finnish legal discussion is more difficulty followed in Sweden than the Swedish discussion in Finland.

All of the above is very true with regard to the legislative culture as well as scientific research and legal education at universities. Still, the daily life in adjudication differs more than the well working collaboration at the legislative field. ${ }^{38}$ The reason for this is that the toolboxes of Swedish and Finnish judges are not identical. Whenever a new interpretation is needed due to the new practical circumstances and needs, if the legislator has not yet reacted with amendments, the Finnish courts normally interpret the valid sections of a law in an instrumental way to reach the best working

\footnotetext{
${ }^{36}$ See for instance Ervo (2015), p. 136.

${ }^{37}$ Sallila (2011), p. 457.

${ }^{38}$ See for instance Letto-Vanamo and Tamm (2019), pp. 2-5 and 14-17.
} 
solution in a new situation. This type of common sense belongs in the toolbox of Finnish judges and is not found to be generally speaking illegal or risky ${ }^{39}$ to do so. ${ }^{40}$ However, this is not the case in Sweden. Especially before joining in the EU in 1995 Swedish courts were very careful and extremely bound to travaux preparatoires and wordings. ${ }^{41}$ Thanks to Europeanisation, this has changed somewhat since the early 2000s. Still, the difference between the neighboring countries is significant in this sense. The more creative Finnish way of interpreting and applying valid sections of laws is strange to Swedish judges. They have not traditionally used these types of creative instruments to interpret in their adjudication, even though recently the Swedish case law has grown more important and judges have become more creative and willing to solve problems within the court. ${ }^{42}$

\section{Main Differences Between East-Nordic Countries}

\subsection{Discuss and Run-Cultural Differences in Reacting}

Some key differences between the Finnish and Swedish legal cultures do exist. ${ }^{43}$ Among these are the differences in efficiency and speed of reforms, in addition to the above-mentioned courts' power to create justice. The Swedish legislative culture is quite dialogic compared with the Finnish one. For instance, travaux preparatoireslike SOU-reports-are very comprehensive and well prepared. It is also typical that a wide societal discussion precedes planned reforms. ${ }^{44}$

This difference concerns not only the legislative culture but the culture as a whole. It is a notorious fact that the Swedish decision-making which aims to achieve consensus is time-consuming, and there are several long-lasting meetings and comprehensive discussions before the final decision. In those occasions, all actors may attend discussions and offer their opinions. ${ }^{45}$ From the Finnish perspective, this kind of decision making is time consuming and not effective. ${ }^{46}$ In Finland, the result is generally more appreciate than the method by which it is achieved.

\footnotetext{
${ }^{39}$ Nor the general audience or guardians of law and order normally find it to be allowed to do so. ${ }^{40}$ Still, this type of Finnish court culture has even been criticised as too passive despite this instrumental approach. Määttä (2011), pp. 207-225.

${ }^{41}$ See for instance Letto-Vanamo and Tamm (2019), p. 7.

${ }^{42}$ Bertilsson (2010), pp. 29-31, Fura-Sandström (2004), pp. 264-265.

${ }^{43} \mathrm{Niemi}$ has compared Sweden and Finland and the named similarities and differences in her article from the legal theory perspective. See Niemi (2018).

${ }^{44}$ Ervo (2015), pp. 144-145 and Kekkonen (1998b), p. 936.

${ }^{45}$ See for instance, https://ruotsi.rajaneuvonta.fi/company/alku/liikekulttuuri-ruotsissa/. Accessed 14 June 2020.

${ }^{46}$ Watch for instance a TV program on the named differences: https://areena.yle.fi/1-1164648. Accessed 14 June 2020.
} 
The Finnish way to 'run things', or to do instead of to discuss (or reflect or analyze), is the main difference between the Finnish and Swedish cultures, and this can be seen very prominently in the legal culture. ${ }^{47}$

\subsection{Judicial Law-Making}

The above-mentioned cultural difference can be one reason for differences in judicial law-making as well, because the common atmosphere and traditions are reflected in courts and affect the work done in them. The decision-making procedures at courts when adjudicating or in the legislature when legislating naturally follow the common culture.

Namely, the court mentality is one crucial factor in so-called judicial activism or judicial law-making and in its opposite-that is, judicial self-restraint. These concepts refer to judges' activity in creating new interpretations and, in difficult cases, even new solutions to problems. Judges can be like passive civil servants who just apply the law more or less technically, or they may closely resemble political actors when they actively create law and up-date interpretations. ${ }^{48}$

The precedents play a significant but practical role in Nordic legal systems. The way in which Nordic law normally tends to identify precedents is highly informative. The Nordic attitude toward precedent describes very well how in the Nordic legal culture the role of the courts and the accompanying role of the legislator are found to be at least partly parallel. ${ }^{49}$ This reveals something potentially important with regard to the Nordic spirit of law, ${ }^{50}$ particularly in Finland as compared to Sweden.

Swedish courts and judges are more bound to the wordings of rules as well as travaux préparatoires compared with their Finnish colleagues, who can make quite finalistic interpretations to find practical and well-functioning solutions, especially in situations where the older legislation does not correspond to the current societal needs and the legislator has not yet reacted. ${ }^{51}$ A search using the term 'fair trial' among the precedents of the Finnish Supreme Court yielded six examples of this, of which five included this type of creative interpretation, especially in the lower courts. ${ }^{52}$ Especially lower courts, and sometimes the minority at the Supreme Court, seem to have a tendency to interpret law quite widely and in an instrumental way. Still, the Supreme Court and especially its majority are still more bound to the wordings of sections of laws.

\footnotetext{
${ }^{47}$ Ervo (2015), p. 145.

${ }^{48}$ Ervo (2015), p. 149 and Hautamäki (2003), p. 171.

${ }^{49}$ Husa (2010), p. 6.

${ }^{50}$ Simoni and Valguarnera (2008), p. 97.

${ }^{51}$ Ervo (2015) p. 145.

${ }^{52}$ The identified cases were The Supreme Court 2016: 98, 88, 85, 84, 76 and 45, of which cases 96, $88,84,76$ and 45 were interesting in this sense.
} 
In the literature, Siltala has stressed that there are two different 'trends' in the Finnish adjudication: namely, the legalistic one and the more creative one. The latter is used especially when European legislation has to be applied to find the more similar interpretation between Finnish and European rules. ${ }^{53}$ Hautamäki is of the opinion that judicial activism is increasing in Finland due to more open norms which delegate more discretion to the courts. ${ }^{54}$ Tuori shares the opinion of Hautamäki and Siltala, saying that activism is increasing and affecting especially EU legislation. ${ }^{55}$

There are also dissenting opinions in the literature. For instance, Mattila wrote in 1998 that judges in Finland and Sweden see themselves as executors of the legislator. ${ }^{56}$ Husa shared the same opinion in 2010 but added that activism in the Nordic countries is increasing. According to him, the role of precedent has also been remarkably weak in the formal and doctrinal sense. One crucial factor the different legal activism between the neighboring countries, is the Finnish and Swedish legal-cultural attitude, according to which moral questions should be left to national Parliaments, not to courts of law, as Husa noted in $2010 .^{57}$

I think that the reason to these different kind of opinions in the legal literature is that the authors do not compare judicial activism with the same standards. It is clear that both Swedish and Finnish courts and judges are careful in a broad sense; they are professional and follow legislation in a respectful way. The amount of offences in office are at a low level, and corruption is not a problem. In addition, there are high levels of control. For instance, ombudsmen are common in both countries, and the threshold to contact them is at a low level because there are not many formalities related to do so and the information is easily at hand. From that perspective, legalism is at a high level in both East-Nordic countries. ${ }^{58}$

Still, at the micro level the difference is essential. ${ }^{59}$ If we compare only Finland and Sweden with each other, we can see that judicial activism does not traditionally exist in Sweden. The requirements of Europeanisation have changed this domestic situation quite comprehensively, but still the activism is limited to those situations where there are no other changes to react to but where courts and judges need to find a harmonious interpretation to follow not only the Swedish national laws but also the demands of the European law. ${ }^{60}$ With regard to judicial self-restraint, it is a question of the level of restraint. It might still be true today that courts are self-restrained in both countries to some degree, but despite this fact there are differences in the Finnish and Swedish mentality in this respect.

\footnotetext{
${ }^{53}$ Siltala (2003), p. 294.

${ }^{54}$ Hautamäki (2003), p. 172.

${ }^{55}$ Tuori (2000), p. 1051.

${ }^{56}$ Mattila (1998), p. 706.

${ }^{57}$ Husa (2010), pp. 7-8.

${ }^{58}$ Ervo (2013a, b), pp. 117-132.

${ }^{59}$ Also, Letto-Vanamo and Tamm have underlined the differences between the single Nordic countries. Letto-Vanamo and Tamm (2019), pp. 1-2.

${ }^{60}$ Bertilsson (2010), pp. 29-31, Fura-Sandström (2004), pp. 264-265.
} 
What was described above is at the same time connected to the sources of law. In Finland, judges use their discretion much more than their colleagues in Sweden do. The differences in culture and mentality lead to a situation in which individual solutions are rare in Sweden and courts wait for the legislator's reaction whenever new solutions are needed. ${ }^{61}$ In Finland, it is not considered risky to make fair and rational decisions in a situation where the law seems to be old-fashioned or otherwise lacking. The same is true in situations where the wording of provisions include the possibility for discretion. In those situations, judges do react and find a solution which works well in practice. They have an instrumental mentality, in which a quick and practical solution is appreciated. It is considered fair to react as a court to solve a problem when the legislator has not yet done so or when the legislator has delegated that power to courts by open and goal-aimed norms. ${ }^{62}$ Often, the Nordic law has been generally found to be practical and concrete, rather than theoretical and abstract, in nature. ${ }^{63}$ Despite these characteristics there are practical and 'more practical' jurisdictions among the Nordic countries. When Sweden and Finland are compared with each other, Finland is clearly the more practical jurisdiction.

In Sweden, on the other hand, these type of situations are normally found as gaps in the legislation, and those gaps in a democracy should be filled by legislative power, not by judicial activism. ${ }^{64}$ However, this is not due only to the different understanding of democracy but also to the common culture which is discursive and communal in Sweden. Legislative procedure corresponds with that type of national culture much better than juridical activism do. Therefore, judicial activism does not fit well into the Swedish court culture and the mentality of judges. Also judges are 'children' of their time and their surrounding society and therefore affected by it. Despite of the education and profession they are affected the more common lifestyle and world view in the society as such.

\section{The Current Situation}

Today, the Finnish legal culture is still characterised by quick solutions and rapid reforms, which can be realised whenever needed through new interpretations in the case law if the legislator has not reacted to relevant new and current needs in the society. This makes flexibility, creative solutions and common sense trademarks of the Finnish legal culture, which has can be illustrated as 'folksy'; in the other words down-to-earth, practical and flexible. ${ }^{65}$ In addition, discretion has in many cases

\footnotetext{
${ }^{61}$ See, for instance, Tuori (2000), pp. 1049-1050. Also, Husa has paid attention to a big role of the parliament in Sweden from the perspective of the constitution. Husa (2019), p. 41.

${ }^{62}$ Ervo (2020), p.

${ }^{63}$ Husa (2010), p. 5.

${ }^{64}$ Holland (1991), p. 2.

${ }^{65}$ Letto-Vanamo and Tamm describe the Nordic legal culture as pragmatic, uncomplicated and realistic. There does not exist unnecessary formality and an uncomplicated and understandable legal
} 
been delegated from the legislator to the adjudicator in the form of open norms and concepts in laws to guarantee flexible solutions in new situations of application. The reasons for this can be found in history. In particular, the periods of Russification have been said to affect the legal culture in a way which still can be seen today. ${ }^{66} \mathrm{I}$ have partly challenged this approach above, but there might be some truth in it still today.

However, the mentality in general varies between Swedes and Finns. Finns are more individual and direct. They are straightforward and enjoy realizing plans, whereas Swedes find more enjoyment in making plans together. Long-lasting discussions with all actors before making a plan or realizing it are trademarks of the Swedish culture as such. This is true in general and not only with regard to the legal culture. This fact probably offers much more clarification than the already quite archaic explanations of Russification and the other historical reasons which were presented above. $^{67}$

The other question is why Swedes are more communal, social, and collaborative compared with the more individualistic Finns. ${ }^{68}$ In Sweden, for instance, the workplace culture is from the bottom up, whereas in Finland it is still more hierarchical, though less so than in the past. ${ }^{69}$ If we do not focus on the DNA and origins of those two people but try to find the societal reasons and explanations, the Swedish 'folkhemmet'-movement can be one explanation. Still today, this ideology of folkhemmet is affecting deeply and in a comprehensive way the Swedish way of thinking and running issues. This difference in cultures can be seen everywhere in the society. Legal culture and court culture are not exceptions to but good examples of these cultural differences and varying ways of thinking.

Some practical differences in national situations also cause cultural differences. As explained above, Swedish society is more multicultural than Finnish society. Almost 20\% of Sweden's inhabitants were born abroad, a rate which is and must be seen in daily-life culture as well. The corresponding number in Finland is 7\%, which is much lower but not insignificant. How this significant proportion of foreignborn residents affects the court culture is an interesting question. In fact, its impacts are visible in daily life, such as in court proceedings where foreigners are parties and should be treated in the same way as native-born citizens. As a matter of fact, its impacts are visible in daily life, such as in court proceedings where foreigners are parties and should be treated in the same way as Swedes. How to reply to this

style is characteristic like transparency, equality, and avoidance of extremes too. Letto-Vanamo and Tamm (2019), p. 9.

${ }^{66}$ Ervo (2015), pp. 143-144 and Sallila (2011), p. 466.

${ }^{67}$ See for instance, https://finlandrelocation.com/en/naapurisopu-suomi-ja-ruotsi/. Accessed 14 June 2020 and https://www.infofinland.fi/fi/elama-suomessa/tyo-ja-yrittajyys/suomalainen-tyokul ttuuri. Accessed 14 June 2020.

${ }^{68}$ See for instance, https://finlandrelocation.com/en/naapurisopu-suomi-ja-ruotsi/. Accessed 14 June 2020.

${ }^{69}$ See, e.g., Bernitz (2018), p. 386 and Isaksson (2008), pp. 16, 20 and 39. 
challenge in practice, is one of current questions. ${ }^{70}$ In addition, there might be latent effects, for instance in the form of stereotypes. ${ }^{71}$ Finland shares the same challenges but so far at a lower level compared with Sweden.

These differences at the micro level, however, do not inhibit Nordic collaboration, for instance in legislative matters. ${ }^{72}$ Due to quite uniform legislation, the court culture is also more or less uniform, but only at the macro level. As explained above, there are some differences in the way of thinking and especially in the way of acting which are important to understand in order to get the correct impression of current East-Nordic court cultures (sic, plural). At the macro level, there is only one East-Nordic court culture, but at the micro level there are both Finnish and Swedish court cultures, which do vary.

\section{References}

Aalto T (1976) Kansakunnan historia 4: Kansakunta kerää voimia 1855-1890. Werner Söderström Osakeyhtiö, Helsinki

Bernitz U (2007) What is Scandinavian law? Concept, characteristics, future. Scand Stud Law 50:13-29

Bernitz U (2018) Nordic law: position and possibilities. Tidskrift utgiven av Juridiska Föreningen i Finland 5:385-391

Bertilsson B (2010) Förändringstendenser i svensk rättskultur: rättskipningens funktion och domarens roll. SvJT 1:23-32

Björne L (2012) Suomalainen legalismi: tarua vai totta? Lakimies 1:146-152

Dahlqvist H (2002) Folkhemsbegreppet: Rudolf Kjellén vs Per Albin Hansson. Historisk Tidskrift 3:445-465

Ervasti K (2005) Tuomioistuinkulttuurin kehityslinjoja. Oikeus 2005:352-375

Ervo L (2013a) Liability and social control of Scandinavian judges. In: Giżyńska M, Piszcz A (eds) Liability of public officers: selected issues. Oficyna Wydawnicza Szkoły Wyższej im. Pawła Włodkowica, Plock, pp 117-132

Ervo L (2013b) Between legal and social control: Scandinavian ombudsmen. In: Annual conference of British institute for international and comparative law. The British Institute for International and Comparative Law

\footnotetext{
${ }^{70} \mathrm{https}: / / \mathrm{www}$. domstol.se/globalassets/filer/gemensamt-innehall/styrning-och-riktlinjer/strategieroch-riktlinjer/bemotandestrategi-for-sveriges-domstolar.pdf. Accessed 14 June 2020 and Ökat förtroende för domstolarna-strategier och förslag-Betänkande av Förtroendeutredningen Stockholm 2008, SOU 2008:106, p. 62.

${ }^{71}$ Torstensson (2010), pp. 95-100.

${ }^{72}$ The Nordic Council, established in 1952, fosters co-operation among parliamentarians from its member nations, Denmark, Finland, Iceland, Norway and Sweden, and autonomous territories, Faroe Islands, Greenland and Åland. The Nordic Council of Ministers, created in 1971, promotes cooperation among government officials. The Nordic Council and its committees tackle, for instance, topics in legislation where the Nordic countries might wish to coordinate their policies. See, e.g., https://nordics.info/show/artikel/nordic-council-and-nordic-council-of-ministers/, https://www.nor den.org/en both accessed 14 June 2020 and Nordic programme for co-operation on legislative affairs (2015-2018)
} 
Ervo L (2014a) Religious affects in civil procedure = Влияние религии на гражданский процесс: East-Scandinavian perspective = восточноскандинавская перспектива. Herald of civil procedure $=$ Vestnik Grazdanskogo Protsessa 4:35-50

Ervo L (2014b) Nordic court culture in progress: historical and futuristic perspectives. In: Ervo L, Nylund A (eds) The future of civil litigation. Access to courts and court-annexed mediation in the Nordic countries. Springer, Cham, pp 383-407

Ervo L (2015) Comparative analysis between East-Scandinavian countries. Scand Legal Stud 61:135-152

Ervo L (2020) Group actions in the East-Nordic legal culture. In: Uzelac A (ed) Class actions: the holy grail or a wrong trail? Springer, Cham

Fura-Sandström E (2004) Rättsbildning i en ny miljö: hur har domstolarnas roll och betydelse förändrats? Domstolarnas roll då, nu och sedan. SvJT 3:263-269

Hautamäki VP (2003) Tuomioistuin Aktivismi Tutkimuskohteena. Oikeus 2003:170-180

Hautamäki VP (2004) Teleologisk tolkningsinställning och judiciell aktivism - några teoretiska synpunkter. Tidskrift utgiven av Juridiska Föreningen i Finland 2:133-150

Holland KM (1991) Introduction. In: Holland KM (ed) Judicial activism in comparative perspective. Palgrave Macmillan, London, pp 1-11

Husa J, Nuotio K and Pihlajamäki H (2007) Nordic law-between tradition and dynamism. In: Husa J, Nuotio K, Pihlajamäki H. (eds) Nordic law-between tradition and dynamism . Intersentia, pp. 1-36

Husa J (2010) The stories we tell ourselves - about Nordic law in specific. Isaidat Law Rev 1:1-17

Husa J (2019) Constitutional mentality. In: Tamm D, Mortensen BOG (eds) Letto-Vanamo P. Nordic law in European context. Springer, Cham, pp 41-60

Inger G (2011) Svensk rättshistoria. Liber, Stockholm

Isaksson P (2008) Leading companies in a global age: managing the Swedish way. Vinnova Report VR 2008:14. Vinnova, Stockholm

Jussila O (2004) Suomen suuriruhtinaskunta 1809-1917. Werner Söderström Osakeyhtiö, Helsinki

Karonen P, Östberg K (2018) Avslutning. In: Meinander H, Karonen P, Östberg K (eds) Demokratins drivkrafter: kontext och särdrag i Finlands och Sveriges demokratier 1890-2020. Skrifter utgivna av Svenska Litteratursällskapet i Finland, Helsinki, pp. 423-435, 492-493

Kekkonen J (1999) Suomen oikeuden historiallisia kehityslinjoa. Helsingin ylipiston oikeustieteellisen tiedekunnan julkaisut, Helsinki 1999

Kekkonen J (1998a) Suomen oikeuskulttuurin historiaa ja paikannusta. Lakimies, pp 929-936

Kekkonen J (1998b) Suomen oikeuskulttuurin suuri linja 1898-1998. Suomalainen Lakimiesyhdistys 100:1-183

Kemppinen J (1992) Tätä kaikki asianomaiset noudattakoot: korkein oikeus, ihmiset ja yhteiskunta 1918-1990

Kemppinen J (1999) Oikeuskulttuuri, in Encyclopædia Iuridica Fennica. Suomalainen lakimiesyhdistys, Helsinki

Kiander J (2001) 1990-luvun talouskriisi Suomen Akatemian tutkimusohjelma: Laman opetukset. Suomen 1990-luvun kriisin syyt ja seuraukset. Valtion taloudellinen tutkimuskeskus, Government Economic Research Center Helsinki 2001

Lehtinen V, Lindholm T, Puukka P, Moring J, Veijola J, Väisänen VE (1995) Onko lama lisännyt mielenterveyshäiriöiden esiintyvyyttä? Duodecim 111:323-329

Letto-Vanamo P, Tamm D (2019) Nordic legal mind. In: Tamm D, Mortensen BOG (eds) LettoVanamo P. Nordic law in European context. Springer, Cham pp 1-19

Mattila HES (1998) Pohjoismainen oikeus, in Encyclopædia Iuridica Fennica. Suomalainen Lakimiesyhdistys 1998:706

Määttä T (2011) Lainsäätäjän kunnioittamisasenne, tavoitteellinen laintulkinta ja lakien tavoitesäännökset vallitsevassa tuomarinideologiassa. In: Pakarinen A et al. (eds) Lainvalmistelu, tutkimus yhteiskunta Jyrki Talan juhlakirja. Turun yliopisto, Oikeustieteellinen tiedekunta, pp 207-225 
Niemi J (2018) Challenges in legal argumentation: A Swedish-Finnish perspective. In: Dahlberg M (ed) Law and society. De Lege: Juridiska Fakulteten i Uppsala Årsbok 2018. Iustus förlag, Uppsala, pp 227-249

Niemi J, Kiesiläinen J (2007) Comparing Finland and Sweden: the structure of legal argument. In: Husa J, Nuotio K, Pihlajamäki H (eds) Nordic law—between tradition and dynamism. Intersentia, pp 89-108

Nordic programme for co-operation on legislative affairs 2015-2018. The Nordic Council of Ministers 2015. https://norden.divaportal.org/smash/get/diva2:799191/FULLTEXT01.pdf.

Nylund A, Øyrehagen Sunde J (2019) Courts and court proceedings. In: Letto-Vanamo P, Tamm D, Mortensen, BOG (eds) Nordic law in European context. Springer, Cham, pp 201-213

Ortwein BM (2003) The Swedish legal system: an introduction. Ind Int Comp Law Rev 2:405-445 Saarnilehto A (2003) Kansallisen oikeuskulttuurin uhat. Lakimies 1:74

Sallila J (2011) Eurooppalainen oikeuskulttuuri, pohjoismainen perinne ja juristi-identiteetti. Oikeushistoria Suomen oikeustieteellisissä aikakauslehdissä n. 1945-1970. Oikeus 4:457-475

Siltala R (2003) Oikeustieteen tieteenteoria. Suomalainen Lakimiesyhdistys, Helsinki

Simoni A, Valguarnera F (2008) La tradizione giuridica dei Paesi nordici. Giappichelli, Torino

Torstensson N (2010) Judging the immigrant accents and attitudes. Umeå Universitet, Department of Language Studies, Umeå

Tuomioistuinlaitoksen kehittämiskomitean välimietintö. Komiteanmietintö 2003:1

Tuori K (2000) Tuomarit ja tuomioistuimet suomalaisessa oikeuskulttuurissa. Lakimies 7-8:1049_ 1050

Viinamäki H et al. 1997.Viinamäki H, Kontula O, Hintikka J, Niskanen L, Koskela K (1997) Laman vaikutus suomalaisten mielenterveyteen. Lääkärilehti 1997(4):1689

Virtanen K O (1974) Ahdistettu kansakunta 1890-1917. Kansakunnan historia 5. Werner Söderström Osakeyhtiö, Helsinki

Yrttiaho E (2000) Tuomarimentaliteteti ja kansan oikeustaju. Oikeudenkäytön representaatiot suomalaisessa kaunokirjallisuudessa ja mediassa käytävässä oikeudenmukaisuuskeskustelussa. Lapin yliopisto, Rovaniemi

Open Access This chapter is licensed under the terms of the Creative Commons Attribution 4.0 International License (http://creativecommons.org/licenses/by/4.0/), which permits use, sharing, adaptation, distribution and reproduction in any medium or format, as long as you give appropriate credit to the original author(s) and the source, provide a link to the Creative Commons license and indicate if changes were made.

The images or other third party material in this chapter are included in the chapter's Creative Commons license, unless indicated otherwise in a credit line to the material. If material is not included in the chapter's Creative Commons license and your intended use is not permitted by statutory regulation or exceeds the permitted use, you will need to obtain permission directly from the copyright holder. 